DOI: $10.31168 / 0459-6.19$

Д. Ю. Ващенко (Москва, Россия)

\title{
Словацкие наречия группы «часто» на фоне венгерских по данным мер ассоциации
}

В докладе на материале Национальных корпусов словацкого и венгерского языка рассматриваются темпоральные наречия с общим значением «часто», семантика которых предполагает, что ситуация повторяется с большей или меньшей регулярностью, причем число подобных повторений представляется говорящему высоким. В ареально близких языках между лексемами, формирующими группу, наблюдается ряд формальных корреляций.

Так, в словацком языке к данной группе относятся лексемы: často (479 938 вхождений в Национальный корпус словацкого языка $\left.{ }^{1}\right)$, neraz (59 093 вхождения), viackrát (41 206), mnohokrát (15 198), velakrát (12 976), častokrát (8609), podchvílou (5586), čochvíla (3545). Наиболее частотным здесь является často, встречаемость neraz и viackrát примерно в десять раз ниже, при этом оба наречия сопоставимы по числу вхождений; относительно распространены и сравнимы между собой по употребительности наречия mnohokrát и vel’akrát.

В венгерском языке группа выстроена несколько иначе. Равный порядок встречаемости имеют сразу три наречия: többször (144118 вхождений в Венгерский национальный корпус $\left.{ }^{2}\right)$, gyakran (142 671) и sokszor (113 592), частотными являются еще два наречия, каждое из которых употребля-

1 Slovenský národný korpus - prim-9.0-public-sane. Bratislava: Jazykovedný ústav L. Štúra SAV 2020. Dostupný z https://korpus.juls.savba.sk 2 Magyar nemzeti szövegtár. V. 2.0.5. MTA Nyelvtudományi Intézet, Budapest. http://corpus.nytud.hu/ 
ется примерно вдвое реже, нежели указанные три, - это rendszeresen (63 681 вхождение) и többnyire (55 633). Также в Корпусе представлены jellemzöen (17 475 вхождений), sürün (11 589) и сравнительно низкочастотные gyakorta (6330 вхождений) и megannyiszor (205).

Будут рассмотрены по пять основных наречий из каждой группы, т. е. с̌asto, neraz, viackrát, mnohokrát и vel'akrát для словацкого языка и többször, gyakran, sokszor, rendszeresen и többnyire - для венгерского. Здесь наблюдается ряд фрормальных соответствий: коррелируют между собой в первую очередь словацкие и венгерские наречия с фрормантом кратности -krát/-ször: mnohokrát, velakrát/sokszor (обратим внимание, что венгерскому наречию соответствует сразу два словацких) и viackrát/ többször. Мы хотели бы рассмотреть, как данные фрормальные соответствия перекликаются с семантическими и каковы общие принципы структурирования семантической группы в каждом из указанных языков.

При анализе мы пользовались показателями корпусной сочетаемости лексем, оперируя данными так называемых мер ассоциации, когда принимается во внимание встречаемость каждого члена соотносительной пары и речь идет о притяжении между двумя выбранными лексемами. Тяготение лексемы к определенному кластеру лексики будет свидетельствовать об актуализации соответствующих сем в ее значении. Из всех доступных в рамках программы NoSketchEngine мер ассоциации была выбрана logDice (вводится в статье [Rýchlý 2008], базирующейся на работе [Dice 1945]), часто применяемая при анализе коллокаций.

В словацком языке в группе выделяются наречия, у которых актуализирована сема кратности - это с̌asto, mnohokrát и velakrát, — и отдельно наречие neraz, семантика которого подобного не предполагает. Neraz отсылает не только и не столько к повторяемым, сколько к сложным и не- 
стандартным ситуациям, т. е. «часто» означает здесь «чаще, чем следовало ожидать». В целом наречие тяготеет к ситуациям в их непосредственном восприятии, проживании cp. коллокации с частицами doslova 'буквально, дословно', dokonca 'буквально, даже', veru 'действительно', ba 'даже'; с лексемами, подчеркивающими значительность ситуации: priam 'действительно, в самом деле', poriadne 'значительно, как следует'. В свою очередь, často, mnohokrát и velakrát, обозначающие типовые, стандартные ситуации, также имеют внутреннюю градацию. Často совмещает в себе собственно фрреквентативное и экзистенциальное значения. В сфреру сочетаемости наречия входят глаголы и причастия с семантикой обнаружения, появления: vyskytovat' sa 'встречаться', vyskytujúci ‘встречающийся', objavovat' sa 'появляться'; фрреквентативные глаголы - vídat' (sa) 'время от времени видеть(ся)', vidavat' (sa) 'время от времени видеть(ся)', chodievat' 'время от времени ходить, навещать' и navštevovat' 'посещать'. Mnohokrát и velakrát, которые являются практически полными синонимами, имеют коллокации с глаголами opakovat' (sa) 'повторяться', zopakovat' (sa) 'повториться'; с адвербиализованной конструкцией na úkor 'за счет чего-л., в ущерб чему-л.'; с глаголами, обозначающими утерю информации: neuvedomovat' 'не осознавать', zabúdat' 'забывать'; с глаголом zažit' 'пережить'. Наречия чаще употребляются в контекстах, предполагающих несоответствие наблюдаемой ситуации и желаемой, в значении «чаще, чем я хочу». Отдельно выделяется наречие viackrát, которое, с одной стороны, точно так же, как mnohokrát и velakrát, сочетается с глаголами, обозначающими непосредственное повторение как таковое, т. е. с оpakovat' (sa) 'повторяться', zopakovat' (sa) 'повториться', вместе с тем высокую меру ассоциации для наречия имеют глаголы с семантикой обнаружения инфрормации либо объекта: stretnút' 'встретить', napadnút' 'прийти на ум', upozornit' 'обратить внимание’. Еще одну, самую об- 
ширную, группу коллокаций для наречия составляют «жанрово отмеченные» сочетания из области криминальной хроники или спортивных комментариев: podržat' 'поддержать', trestane 'по аресту', súdne 'в судебном порядке', deklarovat' 'декларировать', udriet' 'ударить', vyznamenat' 'наградить', vyhrážat' 'угрожать', verejne 'публично', nebezpečne 'опасно', vystrelit' 'выстрелить' и др.

Венгерские наречия, по данным logDice, делятся на жанрово маркированные и жанрово немаркированные. Так, жанровую отмеченность, по данным logDice, демонстрируют többnyire и rendszeresen. У többnyire в верхней части списка оказываются лексемы из тематической сферы «прогноз погоды», ср.: időjárás 'погода', légmozgás 'движение воздуха', hömérséklet 'температура', fok 'градус', nappali 'суточный', napos 'солнечный', zápor 'дождь', zivatar 'гроза', felhö 'облако' и др. У rendszeresen, в свою очередь, частотными оказываются коллокации с лексемами, относящимися к жанру «репортаж», ср.: ellenöriz 'проверять', publikál 'публиковать', fogyaszt 'потреблять', frissit 'освежать', sportol 'заниматься спортом', nézettség 'рейтинг', tájékoztat 'сообщать', konzultál 'консультировать' и др. При этом у többnyire процент глагольной лексики в верхней части списка существенно меньше, нежели у gyakran, sokszor и többször, - 10 глаголов из 60, у gyakran и sokszor их количество равно 25-26, а у többször и rendszeresen - 40-41. Остальные три наречия имеют как пересекающиеся, так и различающиеся части списков. Так, у gyakran признаковыми будут глаголы fordul 'происходить', megesik 'случаться', обозначающие происшествие как таковое, у sokszor - találkozik 'встречаться', szokik 'обычно бывать', подчеркивающие узуальность действия у többször megnövekszik 'расти', elmúlik 'проходить', обозначающие ситуацию в динамике.

Таким образом, в словацком языке основным противопоставлением в группе является оппозиция по стандартно- 
сти/нестандартности частотной ситуации и по ее соответствию/ несоответствию ожиданиям говорящего: často как наречие, немаркированное по данным признакам, представляет собой универсальное наречие для группы. Вместе с тем viackrát, тяготеющее по семантике к mnohokrát и velakrát, демонстрирует жанровую маркированность. В венгерском языке группа в первую очередь делится по жанровостилистической отмеченности наречий. Другими смысловыми оппозициями у венгерских наречий группы «часто», как представляется, являются противопоставления по узуальности / отсутствию таковой и по динамике / стабильности характеризуемой ситуации.

\section{Литература}

Dice 1945 - Dice L. Measures of the amount of ecologic association between species // Ecology. 1945. Vol. 26. No. 3. P. 297-302.

Rychlý 2008 - Rychlý P. A lexicographer-friendly association score // Proceedings of Recent Advances in Slavonic Natural Language Processing, RASLAN 2008 / eds. P. Sojka, A. Horák. Brno: Masaryk University, 2008. P. 6-9.

\section{Slovak Adverbs of the Group 'often' against the Background of Hungarian Ones according to the Association Measures}

In the report, the most frequent Slovak and Hungarian temporal adverbs with the meaning of high repeatability of the situation are considered on the corpus material. The compatibility of lexemes is analyzed according to the indicators of association measures, on this basis, the main trends characteristic of the structuring of the semantic group in each of the two spatially bordering languages are identified. It is shown that the Slovak language, more than Hungarian, tends to semanticize lexemes within a group, as well as to mark non-standard, according to the speaker, situations. 